\title{
От редактора
}

Грустным оказался этот выпуск нашего журнала. Большое место заняла в нем первая глава - Vita brevis, Ars longa. Она посвящена двум значимым и известным людям - Виталию Максимову и Виталию Сотникову. Оба они много сделали для культуры Томска - да и всей нашей страны; оба они покинули наш мир в ноябре этого года. С их уходом, кажется, завершилась целая эпоха - но об этом лучше скажут те, кто гораздо позже посвятит свои исследования истории русской культуры. Остаться в истории культуры дано не каждому; но сейчас еще произошло это слишком недавно, многие помнят их живыми и не стихла еще боль потери.

Но Дело их жизни бессмертно, и это наглядно демонстрируют дальнейшие страницы Альманаха. Непосредственно о них повествует глава «Творческие дороги». Здесь речь идет о встрече В. Максимова с Э. Денисовым (статья С. Вавилова); о В. Сотникове как Человеке (статья Д. Дробышевского) и Мастере (статья С. Вавилова и Я. Ткаленко). Глава «Произведения и персонажи» (статья Вероники Кривопаловой и Ольги Харламовой и статья Ольги Мазепиной) посвящена произведениям наших земляков - композиторов Эдисона Денисова и Константина Лакина. В главе «Технология мастерства» видим три статьи: Кайи Саариахо в переводе Галины Схаплок, Екатерины Приходовской и Никиты Мирошникова, статью Софьи Федотовой. Первые две статьи посвящены технологиям композиторского мастерства, третья - проблемам мастерства певческого искусства.

Рассматриваемые здесь вопросы красноречиво и бесспорно говорят о величии и бессмертии той силы, которой люди посвящают свои земные дороги, - силы Искусства и Творчества.

Итак, уважаемый читатель, доброго пути по страницам «Музыкального Альманаха»! 